\title{
Sessie 12: \\ Evaluatie: hoe blijf ik op de rails?
}

In de laatste sessie blikken we terug. U hebt stappen vooruit gemaakt in het omgaan met lichamelijke klachten en de gevolgen daarvan. Ongetwijfeld blijven er wensen over. Veranderen kost tijd. Het vergt niet alleen overwinningen op de klachten, maar ook overwinningen op uzelf. In dit hoofdstuk staan we stil bij wat er is bereikt. U hebt thuis een brief geschreven over de behandeling. $U$ hebt beschreven waarop $\mathrm{u}$ trots bent en wat $\mathrm{u}$ hebt bereikt. Maar $\mathrm{u}$ hebt ook uw valkuilen beschreven en tips daarbij om die te voorkomen. En ten slotte hebt u voor uzelf een bemoedigend woord geschreven voor momenten dat $u$ het even niet ziet zitten. Bespreek deze brief met uw therapeut. Uw therapeut heeft ook een evaluatie geschreven. Lees deze en bekijk welke punten $u$ hiervan wilt overnemen in uw eigen evaluatie.

Ter afronding komen we nog terug op de casus van Klaas Datema. De behandeling van Klaas is uiteindelijk voorspoedig verlopen. Hij oefende goed, maar zoals $\mathrm{u}$ in hoofdstuk 8 hebt kunnen lezen, had Klaas ook een ernstige terugval tijdens de behandeling. Een bepaalde week sliep hij slecht en werd hij vaker vermoeid en duizelig. Daardoor ging hij ook binnen weer zijn zonnebril dragen en zat hij bij de pakken neer. Samen met zijn therapeut wist hij zijn niet-helpende gedachten als 'ik ben weer helemaal terug bij af' en 'het komt nooit meer goed met mij', uit te dagen en te vervangen door meer rationele en helpende gedachten. Hierdoor kon hij de draad weer oppakken met het oefenen in het nalaten van geruststelling zoeken. Uiteindelijk leerde Klaas steeds beter met zijn lichamelijke klachten om te gaan. Dat wil niet zeggen dat hij helemaal geen lichamelijk klachten meer had, maar hij kon veel beter zijn grenzen bewaken. Zelfs het hardlopen heeft hij weer opgepakt, maar marathons zijn niet meer aan de orde. De klachten van Klaas en met name het aldoor vragen om geruststelling bij zijn vriendin hadden een zware wissel getrokken op hun relatie. Aanvullend hebben zij samen nog een aantal relatiegesprekken gevoerd om hun relatie voor de toekomst te bespreken.

Bij de afronding van de behandeling schrijft de therapeut nog een afsluitende brief aan de huisarts, waar u ook een exemplaar van krijgt. Bespreek samen met uw therapeut wat er in deze brief komt te staan.

Het boek mag dan uit zijn en de therapie afgesloten worden, maar dat betekent niet dat voor $u$ het verhaal ten einde is. $U$ hebt gereedschap en handvaten meegekregen waarmee u hopelijk zelf verder blijft bouwen. 